\title{
Water Justice and Integrated Water Resources Management: Constitutionality Processes Favoring Sustainable Water Governance in Mexico
}

\author{
Heliodoro Ochoa-García ${ }^{1}$ \\ Stephan Rist ${ }^{2}$
}

\begin{abstract}
This research analyzes four ongoing water conflicts in Jalisco state, Mexico, through the lens of constitutionality. Constitutionality refers to a bottom-up institution building process that aims to achieve state recognition of self-created institutions. The process is based on the activation of emic perceptions of people who are often marginalized in policymaking, as well as on alliances with external actors. Results show that the constitutionality concept helps to link the analysis of local people's resistance movements against top-down water policies, with an emerging process of institutional innovation that aims to achieve more sustainable water governance. This process of locally based institutional innovation embodies the principles of water justice, thus transferring these principles from the arena of social movements into the realms of the state, where they become part of its IWRM policy. This analysis provided the basis for the formulation of a conceptual framework that integrates water conflicts, water justice, and IWRM into the concept of constitutionality.
\end{abstract}

Key words. Constitutionality, Water justice, Integrated water resources management, Sustainable water governance, Mexico.

\section{Introduction}

Water conflicts are spreading and intensifying all over the world. In this context, existing water governance institutions are increasingly being questioned, resisted, or rejected. The resulting "global water crisis" is widely acknowledged to be among the top issues of global change, along with, and closely related to, the global food crisis, climate change effects, biodiversity loss, ecosystem collapse, and other man-made environmental catastrophes (World Economic Forum 2016). To address these complex problems, civil society organizations, social movements, and engaged sustainability scientists began to put forward the concept of water justice under the umbrella of environmental justice as a basis for crafting their own institutional frameworks for the reorganization of collective decision-making and action at national to global levels.

For the concept of environmental justice, we refer to Schlosberg (2007) who, based on a powerful critique of liberal theories of justice and their often narrow focus on distribution, offers a more inclusive notion of justice that encompasses recognition, capabilities, and participatory democracy. In the context of water governance, this links well with debates

\footnotetext{
${ }^{1}$ ITESO Jesuit University of Guadalajara and Centre for Development and Environment (CDE), University of Bern. Periférico Sur 8585, 45604 Tlaquepaque, Mexico. E-mail: hochoa@iteso.mx

${ }^{2}$ Institute of Geography, University of Bern and Centre for Development and Environment (CDE), Hallerstrasse 10, 3012 Bern, Switzerland. E-mail: Stephan.Rist@cde.unibe.ch
} 
around water justice, the human right to water, minimum ecological flow, virtual water, ecological footprint, and ecological debt, among others (Martínez-Alier et al. 2016).

The growing importance of these concepts gave rise to new institutions that are being developed from the bottom up, often referring to water justice and integrated water resources management. Scholars and international institutions therefore define the current water crisis as a crisis of governance that is rooted in competing demands for water use, asymmetric power relations, and divergent views among actors regarding the priority of their interests and the specific roles they play in collective decision-making and implementation of water policies (WWAP 2015; Zeitoun and Mirumachi 2008; Castro 2007).

A special feature of water justice movements is that they have grown well beyond their initially local social arenas, into a global policy space in which they operate across broad sectors of society ${ }^{3}$. According to Isch López (2012), water justice approaches and principles can be characterized as follows: a) Water is a disputed resource. Its management implies power relationships and legal issues. Conflicts revolve mainly around unfair and unequal access to and distribution of water resources. b) Water governance is an expression of politics. The management and distribution of water cannot be based only on its biophysical nature and engineering, but also requires consideration of disputed economic and sociopolitical perspectives. c) Striving for water security has become a new source of conflict. Some actors appropriate water as a strategic resource by controlling or diminishing other actors' (individuals', communities', and nations') access to water. d) Conflict and cooperation can complement each other. They play out in history based on changing combinations and interplays of formal and informal institutional mechanisms (Isch López 2012).

Social movements dealing with water conflicts could easily be misinterpreted if they are perceived only as resisting change per se, disregarding that, under certain conditions, they also engage in crafting new institutions aimed at reforming or changing existing forms of water governance. The water justice movement was forged based on cooperation, networking, and participatory practices, in a bottom-up manner and often involving the development of new institutions within and across scales of governance (WWAP 2015).

"Integrated Water Resources Management" (IWRM) is a contemporary paradigm (Allan 2003) that acknowledges the importance of the participation and inclusion of society, governments, social movements, and the private sector as relevant stakeholders in water management. Besides, the concept of sustainable water governance stresses the importance of a deliberative process in "developing a joint understanding of water-related problems and potentials; and taking collective action to transform existing institutions..." (Schneider and Rist 2013, 464). However, deliberation might confront the government authority if the new institutions fail to deliver the desired outcome. Such confrontation

\footnotetext{
${ }^{3}$ For instance, the Latin American Water Justice Alliance is a broad network for research, capacity building and action working on dynamics and mechanisms of water accumulation and conflicts (Zwarteveen and Boelens 2014).
} 
often occurs in situations where the state favors the private sector over society's needs, constricting the potential for cooperation (Ochoa-García and Rist 2015).

Despite the outlined conceptual progress, empirical research usually analyzes water conflicts and the enhancement of cooperation through IWRM separately (RodríguezLabajos and Martínez-Alier 2015; Boelens et al. 2012; Scott and Banister 2008; Zeitoun and Mirumachi 2008). A new approach that aims specifically at analyzing the interplay between resistance to existing institutions of top-down natural resource governance and the emergence of new rules, norms, and social networks of actors involved in water conflicts is the concept of constitutionality presented by Haller et al. (2015). Constitutionality refers to "[...] an institution-building process that highlights natural resource management initiatives from below, analyzed from a perspective that emphasizes community members' views on participation, the strategies they employ in negotiating such initiatives, and the extent to which they can develop a related sense of ownership in the institution-building process for common pool resource (CPR) management" (Haller et al. 2015, 1)4. From this perspective, constitutionality focuses on cross-cutting sociopolitical and institutional aspects related to CPR; hence, the concept is here not related to the otherwise debated questions about how political processes are in accordance with a political constitution of a state.

Constitutionality is at the core of institutional innovations that aim at improving sustainability outcomes of resource governance. Processes of constitutionality can emerge if: (a) local actors are empowered to engage in the institution-building process based on their own perspectives, which can be analyzed emically; (b) these solutions are recognized by the state due to the existence of laws, regulations, and policies that accommodate local action; (c) heterogeneous actors in these contexts, by forming interest groups, can discuss what kinds of institutions, both "traditional" and innovative, they consider important, before negotiating overall regulations; and (d) non-governmental organizations (NGOs) and state actors, despite never being neutral in the institutionbuilding process, find it appropriate to create a relatively open platform for local debates, thereby reducing transaction costs for organizations and catalyzing communicative action for enhancing social learning processes (Haller et al. 2015).

In the present research, we aim to link basic features of resistance to top-down water policies with processes of constitutionality - that is, institutional innovation - arising from the adoption of IWRM as a basis for sustainable water governance. This implies a conceptual shift from analyzing resistance to top-down water management towards a broader view that also looks at the related collective action arising from bottom-up processes of water governance.

This paper addresses two objectives. The first is to analyze to what degree the concept of constitutionality helps to study the cross-scale institutional dynamics resulting from the

\footnotetext{
${ }^{4}$ This concept of constitutionality was developed in different contexts by examining institution-building processes for common pool resource management in four countries: Zambia (fisheries in the Kafue flats floodplain), Mali (Tarabe River banks), Indonesia (fisheries at lake Lindu), and Bolivia (forestry in the Ayopaya Andes).
} 
interplay of resistance to existing institutions and the rise of new institutions. This will be tested based on four case studies in which key actors promote water justice as a fundamental goal of collective action. The second objective is to examine how the case study results might help to conceptualize the relation of constitutionality to the core concepts of IWRM and water justice.

\section{Methods, study region, and case studies}

The research was conducted in Mexico, in the Santiago River watershed, where the presence of water conflicts triggered manifold grassroots institutions. We used a qualitative oriented mixed-method approach to study four cases of grassroots initiatives more systematically. Each case investigated trajectories and institutional arrangements that matched different features of constitutionality processes. Having four different case studies made it possible to uncover enabling and hindering factors related to the emergence of bottom-up institutional innovations, as entailed by the concept of constitutionality.

The empirical work was based on the main author's fieldwork from 2008 to 2015. Information about the stakeholders' emic perceptions and the related institutional transformations was gathered during a three-year presence of the researcher in the area. The methods used were in-depth and intense participant observation, and the application of focus groups, semi-structured interviews, and participatory mapping. In some cases, local actors engaged in strong collaboration with external organizations, making it necessary to also include them in the research process 5 . The plurality of actors involved in water management and case studies was simplified by clustering them into interest groups engaged in the processes of constitutionality. Additional insights were generated by organizing meetings at which main research results were presented. These meetings provided access to views expressed in internal discussions about agreements and disagreements between social leaders, government representatives, and researchers, that were not always shared publicly. Using these methods, we identified perceptions and values related to water governance and water use. An abundant body of previously published qualitative and quantitative studies on water conflicts and local stakeholders' views, collaborative efforts, and institutional alternatives for water governance was used to cross-check and complement the analysis (Ochoa-García 2015; Ochoa-García et al. 2014; Schneider and Rist 2013; Tetreault et al. 2012).

\section{Study region and case study localization}

From a national point of view, some of the most significant features of the study region are of particular interest. To begin with, Lake Chapala is the largest freshwater reservoir in the country $\left(1147 \mathrm{~km}^{2}\right)$. The Santiago River carries up to 1090 pollutants, some of them

\footnotetext{
${ }^{5}$ Some external key actors are representatives of: New Water Culture Foundation (Spain); project on Environmental Justice Organizations, Liabilities and Trade (EJOLT); Waterlat-Gobacit Network (Latin America and other countries); The United Nations Office for Project Services; Latin American Water Tribunal; the "Absent Sons and Daughters" (emigrants) from Temacapulin town living in the US.
} 
highly toxic (IMTA and CEAJ 2011). It has 18 dams, four of which belong to big hydroelectricity plants. The upper watershed comprises Altos Region, the country's most important livestock-producing region and El Zapotillo dam, a highly contested project that has been subject to legal battles since 2005. Guadalajara is the second biggest city in the country, and a large industrial corridor of $80 \mathrm{~km}$ length connects Chapala and Guadalajara (Ochoa-García and Rist 2015; Ochoa-García et al. 2014; Ochoa-García and Bürkner 2012; Tetreault et al. 2012).

Fig. 1. Location of case studies

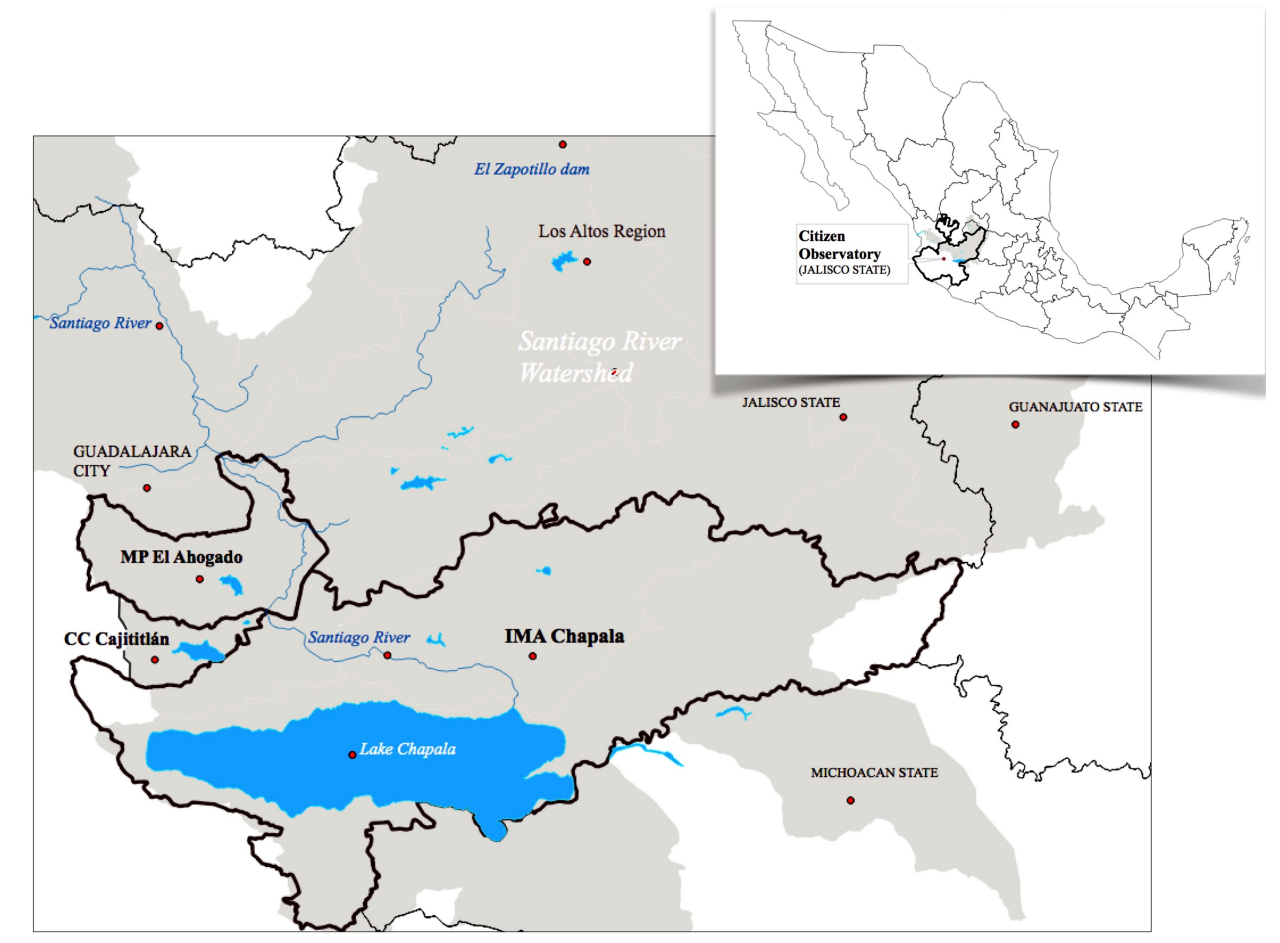

So far, water supply has been the top priority in water policy in the Santiago River watershed. Despite efforts by the state and federal water authorities to develop infrastructure to satisfy the fast growing urban and agricultural demand for water, the infrastructure has so far been unable to cover this demand (Wester et al. 2009). In Guadalajara city, the population has grown by $49 \%$ over the last 20 years and has reached 4.4 million; industrial and rural development have further amplified the pressure on water resources. The "green" area the city depends on for its water supply has expanded from local springs and aquifers to include lakes and rivers within a $90-\mathrm{km}$ radius; the regional water balance and the distribution of water rights in the basin is rapidly changing (LópezRamírez and Ochoa-García 2012). In the meantime, wastewater discharge is left untreated, hydro-ecosystems continue to deteriorate, wetlands are drying up, biodiversity is depleting, people living near the rivers are increasingly facing health problems, and water-related sociocultural practices are disappearing (McCulligh et al. 2016; Tetreault et al. 2012). Embedded in this context, social conflicts take place at different levels of water governance. Every local conflict has a particular context, dynamics, and spatial 
scope. In this sense, the case studies are helpful in gaining a better understanding of multiscale constitutionality processes from local to regional (subnational) levels. The first case presented in this paper is the "Citizen Council for Integrated Sustainable Management of Lake Cajititlán" (CC Cajititlán), which is found in a closed catchment inside one single municipality. The second case is the Municipal Platform "Polygon of Environmental Fragility El Ahogado" (MP El Ahogado), which covers a catchment encompassing urban and suburban areas. The third case involves the Intermunicipal "Association for Environmental Protection and Sustainable Development for Lake Chapala" (IMA Chapala). The fourth case is a regional initiative named "Citizen Observatory for Integrated Water Management" (Citizen Observatory). Fig. 1 shows the geographical location of the interventions by the state that triggered the social movements analyzed in our four case studies.

Pointing to the fast-growing need for water in urban areas, industry, and "modern" agriculture, the government promotes and implements a huge system of hydraulic infrastructure such as dams, aqueducts, and wastewater treatment plants, which do not always successfully function (Ochoa-García et al. 2014). This policy has resulted in severe levels of water pollution, human rights violations, adverse impacts on human health, economic loss, environmental damage, and destruction of cultural practices (CEDHJ 2009). The situation had led to the emergence of internationally renowned social movements and networks in which activists and researchers struggle to include the principles of water justice into the further process of renegotiating water policy between local to regional societies and the various levels of the state. The study area is a highly interesting context where water conflicts are addressed through new local-level institutions developed from the bottom up, embracing and integrating principles of water justice and IWRM as complementary elements in a cooperative relationship with the state.

\section{Water conflicts and the emergence of new institutions in the Santiago River watershed}

This section analyses the situation in the Santiago River watershed, where major water conflicts have sparked the creation of new institutions mainly dealing with water pollution and opposition against big dams, aqueducts, and water transfers. For each case, we analyzed the problems that arise when local movements introduce new rules, norms, and regulations that aim at making existing water policy more responsive to the principles of water justice and IWRM, eventually contributing to the development of alternative institutions required for more sustainable water governance. These alternative institutions cover local to multiples scales, ranging from a small closed catchment and an intermunicipal basin to a metropolitan area or up to a subnational level. Finally, we assessed the resulting institution building based on the key concepts entailed by constitutionality. 
According to the Mexican water law, IWRM is "a process that promotes the management and coordinated development of water, land, resources related to them and the environment, in order to maximize equitable social and economic welfare without compromising the sustainability of vital ecosystems..." (Semarnat 2004); additionally, river basins and aquifers are a matter of public interest. Scott and Banister (2008) argue that IWRM is difficult to achieve, mainly because the political and territorial disputes of stakeholders involved in water management are difficult to mitigate. An additional difficulty is that IWRM demands a complex institutional organization for a successful operation, which is often not available - and yet the focus in practice is still on the river basin councils, which are too narrow in focus. As a result, water users and people living in suburban and rural areas feel excluded from public decision-making in water management (Ochoa-García et al. 2014). This is seen by local actors as a reason for growing rates of appropriation of collective land and water property rights of local private and public actors to private businesses; these are engaged in the management of the water infrastructure related to housing, agribusiness, energy, and industry, enhancing private control over natural resources (Reis 2014).

The asymmetries in how different stakeholders' interests are considered have not only generated water-related conflicts, but also encouraged people to create initiatives and new institutions to better meet the complex challenges of sustainability according to their emic perception of their problems and needs. The National Water Commission (CONAGUA) opposes these kinds of initiatives (Scott and Banister 2008). However, a growing number of movements currently aim at weakening CONAGUA's monopoly, considered as "a unique water authority, the biggest institution in the world according to its functions and power" (Gobierno de México 2012, 18). Regardless of the political affiliation, in Jalisco state, social organizations, scholars, universities, political parties, and some federal representatives are pushing for alternative solutions to dams, water transfers, and privatization of expensive infrastructure. Social protests and environmental justice movements grew to global proportions, and there was a tacit belief that the private sector had not succeeded in providing water and sanitation services (Bakker 2013).

The expansion of big infrastructure for water storage and supply progressed steadily, leaving behind the IWRM perspective and generating social conflicts all over the country. Consequently, from 2000 onwards, local to national civil-society organizations that had so far strongly focused on environmental issues, increasingly linked up with the emerging water justice discourse, which had become more visible and more organized based on its own social movements (Mcculligh and Tetreault 2017; Toledo et al. 2015). High numbers of social groups emerged and began to fight against the contamination of water resources, while also rejecting top-down hydraulic projects.

The water-related problems and social conflicts have prompted public attention and a greater openness on the part of governmental instances for dealing with people's judicial claims and including them in the relevant socio-technical debates. People are increasingly starting to focus on the plight of those displaced by huge hydraulic infrastructure and on IWRM, the human right to a healthy environment, good living (vivir bien), the right of 
access to information - and are looking for ways to determine their own future through decisive democratic decision-making. During the fieldwork, these aspects were found to be at the core of the social movements. These movements organized meetings, public forums, and scientific field research (on water quality, environmental issues, and public health), looking for alternative solutions from the bottom up.

It was also observed that the presence of engaged scientists helped the emerging social movements to ally themselves with outside agents providing scientific support in public debates and judicial claims. For instance, within the study area social groups and scholars have developed joint research on water quality, human health effects, water availability and distribution, and related human rights violations near the Santiago River and El Ahogado stream (McCulligh et al. 2016; Ochoa-García et al. 2014; Ochoa-García and Bürkner 2012; Tetreault et al. 2012). Social platforms of collective knowledge and action were organized in line with the principles of environmental justice, e.g. the National Assembly of Environmentally Affected (ANNA), the Mexican Movement of Peoples Affected by Dams and in Defense of Rivers (MAPDER), the Coalition of Mexican Organizations for the Right to Water (COMDA), and several regional assemblies of people environmentally affected. Platforms such as these usually also have alliances with international networks such as "International Rivers" or the "Permanent Peoples' Tribunal". The "Water, Rivers and People Foundation" supported and documented the local struggles for an international photo project which exhibits similar cases around the world; similarly, the Environmental Justice Atlas registered two of our case studies for worldwide dissemination (www.aguariosypueblos.org; www.ejatlas.org).

There emerged throughout the country numerous political initiatives that opposed the construction of dams for hydroelectricity and urban supply, aqueducts for interbasin transfers, water treatment plants, water (re)allocation agreements, and privatization of water services. Salient examples of such initiatives are in the study region: Arcediano, San Nicolás, and the El Zapotillo project. Such government projects have been obstructed by communities, social movements, and networks (Mcculligh and Tetreault 2017; Toledo et al. 2015). El Zapotillo is probably the most contested project in the country, accounting for more than a hundred legal and judicial processes in court.

\section{Key features of the case studies and related outcomes and institutional dynamics}

The most significant factors triggering bottom-up institutional processes in the four cases studied were related to (a) environmental degradation and high pressure on water resources with negative effects on livelihoods, (b) top-down hydraulic interventions with inadequate levels of participation, (c) water conflicts in which local actors aim at changing priorities, values, and procedures of governmental water policy as a basis for renegotiating the technical and institutional design of ongoing and future water infrastructure, and, (d) the experiences resulting from long-lasting social mobilization of generally marginalized stakeholders that are kept out of water governance.

Table 1 summarizes the geographical and hydrological context, the main features of water management and infrastructure, and the problems related to water conflicts. 
Table 1. Key features of case studies regarding geography, water management, and water conflicts.

\begin{tabular}{|c|c|c|c|}
\hline Case study & $\begin{array}{c}\text { Geographical and hydrological } \\
\text { context }\end{array}$ & $\begin{array}{l}\text { Water management and } \\
\text { infrastructure }\end{array}$ & $\begin{array}{c}\text { Problems related to water } \\
\text { conflicts }\end{array}$ \\
\hline $\begin{array}{l}\text { Citizen Council } \\
\text { (CC Cajititlán) }\end{array}$ & $\begin{array}{l}\text { Closed catchment; presence of } \\
\text { indigenous communities; traditional } \\
\text { lifestyles as tourist attraction; pressure } \\
\text { on quantity and quality of water and } \\
\text { groundwater from increasing urban } \\
\text { population, industrial growth, and } \\
\text { discharge of polluted water. The } \\
\text { municipality has one of the highest } \\
\text { urban growth rates in Mexico. }\end{array}$ & $\begin{array}{l}\text { One-third of the lake was } \\
\text { drained in 1948; inadequate } \\
\text { management of channels; } \\
\text { increasing number of wells for } \\
\text { agricultural, urban, and } \\
\text { industrial uses; deficient water } \\
\text { treatment plants. The whole } \\
\text { lake has been drained twice to } \\
\text { maintain urban supply in dry } \\
\text { years }(1955,2001) \text {. }\end{array}$ & $\begin{array}{l}\text { Communities living on the shores of } \\
\text { Lake Cajititlán see their livelihood } \\
\text { options reduced due to pressure on } \\
\text { their land, eutrophication, reduction } \\
\text { of fish populations, and floods } \\
\text { caused by inadequate management } \\
\text { in upper catchment areas. Lack of } \\
\text { proactive regulation of socio- } \\
\text { economic and ecological problems. }\end{array}$ \\
\hline $\begin{array}{l}\text { Municipal } \\
\text { Platform (MP El } \\
\text { Ahogado) }\end{array}$ & $\begin{array}{l}\text { Ten municipalities share the El Ahogado } \\
\text { basin and environmental degradation is } \\
\text { widespread. This is the most polluted } \\
\text { stream in the region: it receives } \\
\text { untreated water from industry and urban } \\
\text { areas, and there is occasional flooding. } \\
\text { Confluence with the Santiago River near } \\
\text { a waterfall. The whole area is subject to } \\
\text { rapid, inappropriate land use changes. }\end{array}$ & $\begin{array}{l}\text { Water rights are shifting from } \\
\text { agriculture to more profitable } \\
\text { uses; natural areas are under } \\
\text { pressure from private interests } \\
\text { and urban infrastructure; the } \\
\text { aquifers are the most } \\
\text { overexploited in the state, } \\
\text { lowering the level by } 2 \text { meters } \\
\text { per year. Mix of several } \\
\text { pollutants in water; a waterfall } \\
\text { increases negative effects on } \\
\text { human health and ecosystems. }\end{array}$ & $\begin{array}{l}\text { People claim that water pollution } \\
\text { impacts the health of over } 30,000 \\
\text { inhabitants; social groups collect } \\
\text { information and evidence for legal } \\
\text { actions. Human rights } \\
\text { recommendations claim that the } \\
\text { Mexican government is failing to } \\
\text { effectively enforce its laws related } \\
\text { to water resources management. } \\
\text { After } 2000 \text {, a significant increase in } \\
\text { support from networks and media. }\end{array}$ \\
\hline $\begin{array}{l}\text { Intermunicipal } \\
\text { Association for } \\
\text { Environmental } \\
\text { Protection and } \\
\text { Sustainable } \\
\text { Development for } \\
\text { Lake Chapala } \\
\text { (IMA Chapala) }\end{array}$ & $\begin{array}{l}\text { Lake Chapala is the largest natural } \\
\text { freshwater reservoir in Mexico; its } \\
\text { storage level has repeatedly been } \\
\text { critically low due to increasing demand } \\
\text { and reduced rainfall in the watershed. } \\
\text { Indigenous communities depend on the } \\
\text { lake for their livelihoods. Presence of } \\
\text { thermal springs. }\end{array}$ & $\begin{array}{l}50,000 \text { hectares of lake } \\
\text { surface were drained in } 1902 . \\
\text { Since } 1957 \text { the lake provides } \\
60 \% \text { of water for } 4 \text { million } \\
\text { inhabitants in Guadalajara } \\
\text { city. Rise in dam storage in } \\
\text { the upper watershed, overuse } \\
\text { of water; export agriculture. } \\
\text { Guadalajara city needs more } \\
\text { water, but locals have } \\
\text { opposed further extraction. } \\
\text { Lack of safe drinking water in } \\
\text { lakeside towns. }\end{array}$ & $\begin{array}{l}\text { Impact on local communities living } \\
\text { on the lakeshores; loss of } \\
\text { biodiversity and reduction in fish } \\
\text { capture. Land change and soil loss } \\
\text { on the hillsides is affecting the } \\
\text { livelihoods and traditional practices; } \\
\text { land speculation. Variability in } \\
\text { tourist activities. Interstate } \\
\text { agreements for water distribution } \\
\text { and extractions affects the lake } \\
\text { ecosystem. High rates of people } \\
\text { suffering from renal diseases. }\end{array}$ \\
\hline $\begin{array}{l}\text { Citizen } \\
\text { Observatory } \\
(\mathrm{CO}) \text { for } \\
\text { integrated water } \\
\text { management }\end{array}$ & $\begin{array}{l}\text { Jalisco state has few perennial rivers, } \\
\text { temporary streams, shallow lakes, and } \\
\text { accessible aquifers, all of which depend } \\
\text { on summer rainfall. A majority of } \\
\text { people in the state }(60 \%) \text { live in } \\
\text { Guadalajara city. }\end{array}$ & $\begin{array}{l}\text { Hydraulic projects are for the } \\
\text { collective good, but } \\
\text { privatization of the } \\
\text { administration of } \\
\text { infrastructure and water } \\
\text { services is underway. The } \\
\text { most important hydraulic } \\
\text { projects and the biggest } \\
\text { investments benefit urban } \\
\text { areas. }\end{array}$ & $\begin{array}{l}\text { The environmental conflicts in } \\
\text { Jalisco are mainly linked to } \\
\text { untreated wastewater discharge, big } \\
\text { hydraulic infrastructure, interbasin } \\
\text { water transfer, lack of water in } \\
\text { some places, and displacement of } \\
\text { people by dams. Top-down water } \\
\text { policies are contested; legal actions } \\
\text { are filed in court. }\end{array}$ \\
\hline
\end{tabular}

\section{Citizen Council for Integrated Sustainable Management Lake Cajititlán (CC Cajititlán)}

In the case of CC Cajititlán, a key feature is the election of a new political party with high levels of legitimacy and legal powers which has run the municipal government since 2010. The citizen council CC Cajititlán was established by the villagers in 2008: their main goal is to have a clean lake, protect forests in the catchment, and strengthen the area as a tourist destination to boost the local economy.

Their policy is based on a combination of more participatory institutional arrangements used in the implementation of complex and expensive projects for the improvement of the lake. These include ecological lake restoration, fishing, hiking trails, organic farming, 
tourist development, collective land management, environmental education (formal and informal), art and handicrafts, and territorial planning. Because water is matter of federal regulation, CC Cajititlán founded in 2017 a basin committee, which serves as an auxiliary institution for water management and is now entitled to receive funds from the federal government. The municipality also created a new institution comprising the first local prosecution office in the country to deal with environmental protection and water justice and able to enforce its decisions through sanctions for crimes against common resources (air, soil, water, flora, and fauna). The CC Cajititlán helped to gather key information for the local prosecution office, leading to an action plan in the lake area. The people also participated in designing the new infrastructure for controlling discharge and storage levels of the lake. Such institutional innovations represent fundamental principles of IWRM by enhancing subsidiarity in sustainable water governance, which in turn permits organization of the design and implementation of lake restoration and socio-economic welfare at adequate levels of governance.

\section{Polygon of Environmental Fragility El Ahogado (MP El Ahogado)}

The MP El Ahogado is an interinstitutional platform in which ten municipalities address environmental deterioration and water pollution in the area. Since the early 2000 s, people have claimed that the El Ahogado river carries industrial pollutants that affect human health and the livelihoods of 30,000 people, especially those living near the waterfall at which the El Ahogado river joins the Santiago river. The area also contains a solid waste disposal facility in which 2,500 tons per were deposited during three decades and later covered with soil. The landfill area is deficiently managed and a continuous source of polluting residues into the river (Ochoa-García and Bürkner 2012).

The villagers organized resistance and began to expose the environmental problems by giving public statements, producing materials, holding meetings among concerned citizens, and offering open tours to the area, among others. After reviewing the 127 social complaints made by local organizations, the State Commission for Human Rights in Jalisco presented in 2009 its most extensive report, recognizing the violation of human rights related to water and the environment.

This increased media attention and support from scholars, NGOs, institutes, universities, foundations, and some political representatives considerably. In response to the rise in social mobilization, the government issued a decree in 2010 declaring the area "environmentally fragile". This meant that conservation must be prioritized for an indefinite time and strategic planning must be coordinated from local to federal level by including all relevant and interested stakeholders. This resulted in the development of an action plan for ten municipalities with two million people (Semadet 2013). In order to comply with the human rights recommendations, the plan was jointly defined, and based on the principles of integrated watershed management, recognition of political rights, the knowledge and interests of formerly marginalized actors, and effective law enforcement. In spite of this progress, the government's water management policy is still criticized by the social movements, as the area is still far from attaining effective ecological restoration. The criticism points among other issues to a flaw in the IWRM discourse of 
the government, which aims at orienting its IWRM policy towards private concessions for hydraulic infrastructure and services (Ochoa-García and Rist 2015).

\section{Inter-Municipal Association for Environmental Protection and Sustainable Development for the Lake Chapala (IMA Chapala)}

In the case of IMA Chapala, the institutional innovation in water governance is related to the first watershed council in the country, established in 1993 after a series of significant interventions in the watershed. In the early $20^{\text {th }}$ century, the surface of Lake Chapala was reduced by $30 \%$ (50,000 hectares) for the expansion of agriculture, although a dike was made to increase the lake storage by almost 50\%. Historically, the Lerma-Chapala watershed has been characterized by high pressure and overexploitation of water caused by the demands of urban settlements, irrigation, and industry (Wester et al. 2009). Lake Chapala has been the main source of water to Guadalajara city since 1957 (requiring 240 million cubic meters annually), and plays an important role in the livelihoods of the communities of the lakeshore. The quantity and quality of water fluctuates around critical levels due to the high demand for water, retention of water for reserves in upstream reservoirs, varying rainfall periods, and changes in land use. At present, the city of Guadalajara has 4.4 million inhabitants demanding ever more water. Meanwhile, the people living near the lake have rejected calls to increase the extraction of water without taking integrated measures for the watershed.

In 1991 and 2004 the city government and CONAGUA (National Water Commission) signed agreements permitting an increase in social participation in water governance. Several hydraulic management and water security projects have been implemented, involving business organizations (industrialists, farmers, and breeders), Guadalajara city representatives, political parties, scientists, and environmental organizations. In 2011 IMA Chapala was established by 16 municipalities working on territorial planning for hydrological protection, updating of environmental regulations, control of land use change, and waste management programs. They have a long-term portfolio of projects and have been recognized as a decentralized public organism, making it possible to become the local manager of the long-term UN Program for Reducing Emissions from Deforestation and Degradation (REDD+) project, which aims at creating a natural protected area of $190 \mathrm{~km}^{2}$. The shift from water to forest issues has increased government support for IMA Chapala, and allowed water justice and IWRM to be linked with climate change mitigation and adaptation.

\section{Citizen Observatory (CO) for Integrated Water Management}

The Citizen Observatory can be considered the most significant institutional innovation in water governance in the state of Jalisco. It is the country's first citizen institution holding legally binding powers for the enforcement of rules related to water issues in Jalisco state. The institution emerged from a water conflict in which the water users in the Altos Region formed their own basin council for democratic decision-making in 2008. The Citizen Observatory was jointly developed by the Jalisco state government, the people affected by the El Zapotillo hydraulic project, water users, and outside supporting institutions. Based on pre-existing institutions and failures in water governance (e.g. 
deficient inclusion of grassroots organizations, limited accountability of projects, lack of collective decisions), the participants wrote their own "constitutional rules" for this new institution in a self-driven initiative. The Citizen Observatory was launched in 2014, with twenty founding members including representatives from civil society, universities, entrepreneurs' organizations, rural producers' organizations, and the Catholic church (Gobierno de Jalisco 2014).

\section{Processes of constitutionality}

The main features of the institutional innovations represented by the case studies are summarized in Table 2. The institutional processes are reviewed following the constitutive elements of constitutionality processes as defined by Haller et al. (2015), i.e.: emic perceptions of the need for new institutions, participatory processes of negotiation, pre-existing institutions as a basis for institution building, outside catalyzing agents, recognition of local knowledge, and a higher level of recognition and support for the new institutions.

The analysis of the emic perceptions that motivated citizens to intervene in water governance reveals interesting contrasts regarding the topics of dissent, the type of power relations, and the governance scales involved. The scales of the four cases range from local action arenas (CC Cajititlán and MP El Ahogado) to the intermunicipal (IMA Chapala) and subnational level (Citizen Observatory). The analysis of these showed that the emic perceptions at local level focused on health, impacts on livelihoods, and environmental damage (Ochoa-García 2015; Tetreault et al. 2012; Velázquez-López et al. 2012). When moving towards broader contexts of water policy, the focus of emic perceptions shifts towards a critical review of procedural issues of political participation and the asymmetric appropriation of the benefits of existing and projected water megainfrastructures by the economic and political elites, coupled with the transfer of socioecological costs to the local actors (Ochoa-García and Rist 2015).

A scale-related tendency was also observed regarding the participatory processes and the types of power asymmetries involved. At local levels, problem framing clearly revolves around the unjust distribution of negative health and livelihood impacts among "winners" and "losers" of current water policies (Ochoa-García and Bürkner, 2012). Therefore, institutional innovations in these cases focus on concrete measures that consider the needs of local people and their environment. These measures may be related to sanitation, territorial planning, organic agriculture (avoidance of pesticides that contribute to the pollution of lakes and rivers), or regulation and improvement of tourism activities. A particularly interesting local-level institutional innovation is the establishment of the local prosecution office, which not only enables local actors to issue new policies, but also empowers them to effectively enforce these policies by means of their own sanctions. The Citizen Observatory is perhaps the most novel institution that considers stakeholder diversity and regional scope. Most significantly, it can take legally binding decisions, which sets it apart from other participatory entities such as basin councils. 
Table 2. Components of constitutionality and institutional innovation in the Santiago River watershed.

\begin{tabular}{|c|c|}
\hline $\begin{array}{l}\text { Component } \\
\text { Constitution }\end{array}$ & $\begin{array}{l}\text { Case studies } \\
\text { CC Cajititlán = Villagers” organization “Citizen Council for Sustainable Management of Lake Cajititlán” } \\
\text { MP El Ahogado = Municipal platform "Polygon of Environmental Fragility El Ahogado" } \\
\text { IMA Chapala = Intermunicipal "Association for Environmental Protection and Sustainable Development for } \\
\text { Lake Chapala" } \\
\text { Citizen Observatory = Citizen Observatory for Integrated Water Management in Jalisco State }\end{array}$ \\
\hline $\begin{array}{l}\text { eption of } \\
\text { ating need for } \\
\text { tions / } \\
\text { rstanding of }\end{array}$ & $\begin{array}{l}\text { CC Cajititlán: deterioration of Lake Cajititlán affects the livelihoods; government's irresponsibility. } \\
\text { MP El Ahogado: severe pollution of the Santiago River and El Ahogado stream; high level of environmental } \\
\text { deterioration causing health issues; industrialists' irresponsibility and ecological debts; round tables for collective } \\
\text { definition of the problem. } \\
\text { IMA Chapala: Lake Chapala is threatened by hydraulic interventions, water extraction, and a negative water } \\
\text { balance; the catchments are wrongly managed and polluted. Unsafe drinking water is related to public health } \\
\text { problems in lakeside towns. } \\
\text { Citizen Observatory: top-down decisions lead to water conflicts; prevalence of centralized "hydraulic mission" } \\
\text { policy; government decisions ignore relevant stakeholders' opinions and knowledge; water resources are in critical } \\
\text { condition. }\end{array}$ \\
\hline $\begin{array}{l}\text { Participatory processes } \\
\text { addressing power } \\
\text { asymmetries and giving } \\
\text { a sense of ownership / } \\
\text { Collective action to } \\
\text { challenge existing } \\
\text { institutions and policies }\end{array}$ & $\begin{array}{l}\text { CC Cajititlán: wide representative participation of lakeshore communities in the definition of a work agenda. } \\
\text { MP El Ahogado: joint definition of the area (polygon) in which to intervene; participation of all relevant } \\
\text { stakeholders in assessment as well as restoration program. } \\
\text { IMA Chapala: multilevel participation in debates and basic agreements on water distribution, sanitation, and } \\
\text { environmental protection; municipal, regional, and national interest gave rise to novel institutions for water } \\
\text { management and forest protection. } \\
\text { Citizen Observatory: aim for horizontal dialogue between authorities, users, people interested in water issues, and } \\
\text { communities affected by hydraulic infrastructure; creation of the first binding citizen institution for IWRM; } \\
\text { representation of all segments of society creating an explicit sense of ownership. }\end{array}$ \\
\hline $\begin{array}{l}\text { Tapping } \\
\text { institutior }\end{array}$ & $\begin{array}{l}\text { civil-society organization "Por un Lago Limpio"; basin commission acknowledged by the federal } \\
\text { do: civil-society organizations; formal institutions from the local to the federal level; decree for } \\
\text { among institutions, governments, civil society, and experts. } \\
\text { interstate initiative; basin council for Lake Chapala and intermunicipal entities. } \\
\text { vatory: basin commission; civil-society and producers' organizations from Los Altos, Guadalajara } \\
\text { hers; collaboration among relevant stakeholders working on water conflicts. }\end{array}$ \\
\hline $\begin{array}{l}\text { Inte } \\
\text { bro }\end{array}$ & $\begin{array}{l}\text { ks. } \\
\text { nternational); co-production of } \\
\text { ng the people's concerns. } \\
\text { ological justice networks; social } \\
\text { holars; environmental and water }\end{array}$ \\
\hline $\begin{array}{l}\text { Rooting and } \\
\text { contextualization of } \\
\text { initiatives }\end{array}$ & $\begin{array}{l}\text { la: wide-ranging studies incorporate the values } \mathrm{p} \\
\text { radictory IWRM measures taken by Guadalajara } \\
\text { ervatory: the broad participation and multiple }\end{array}$ \\
\hline $\begin{array}{l}\text { Forn } \\
\text { assi } \\
\text { resp }\end{array}$ & $\begin{array}{l}\text { modifications according to local values. } \\
\text { ree, shared work plan. } \\
\text { forest issues due to adoption of UN REDD+ program. } \\
\text { participants defined their own frame and attributions } \\
\text { mendations. }\end{array}$ \\
\hline $\begin{array}{l}\text { ent in } \\
\text { and control of } \\
\text { ce of policy }\end{array}$ & $\begin{array}{l}\text { an: approval of the citizen initiative by the local government and budgeting for implementation; } \\
\text { ent of the country's first local-level environmental prosecution office. } \\
\text { ogado: people's claims are supported by official acknowledgement and decree; budget for sanitation } \\
\text { Ire; failure to address human rights recommendations. } \\
\text { ala: acknowledgement of IMA Chapala as effort in favor of climate change mitigation and adaptation; } \\
\text { ilable for implementation. Increasing support from local government and environmental entities. } \\
\text { servatory: The observatory's capacity and legitimacy is attracting cases of water conflict occurring in } \\
\text { e; this novel institution has received recognition for its commitment and active involvement in the } \\
\text { sustainable water governance. }\end{array}$ \\
\hline
\end{tabular}


In the case of the MP El Ahogado, participation revolves around issues of improving the environmental accountability of various government bodies by creating options for intervention and mobilizing citizens for the evaluation and monitoring of powerful actors' impact, which is turning this area into a hotspot source of environmental pollution through industrial and artisanal activities.

On a broader scale - at intermunicipal to regional levels - participation directly targets intervening governmental instances and policymaking arenas, mainly with regard to processes of planning, construction, and overseeing of water-related infrastructure. Participation in these cases attempts to link governmental top-down water governance with the new institutions created from the bottom up, in response to the currently deficient and centralized water governance system.

Regarding pre-existing institutions, there are local to regional instances of water governance from which social mobilization could develop into new forms of collaboration. The claims of local people mainly draw political legitimacy from existing, but not yet enjoyed, rights codified in local, regional, federal, and international laws or agreements. On this basis, the social movements also address different political arenas in which these policies play out, such as in communities, municipalities, and regional governments. From there, they legitimize the political actions institutionalized for different purposes by enhancing participation.

The roles of outside actors have a strong legitimizing influence in all four cases. Comparing local to regional institutional innovation, we observe that support at the local level focuses on alliances with water justice networks, civil-society organizations, engaged experts, and scientists from regional universities. At broader scales, the local supporting actors serve as catalysts in obtaining support from larger organizations, ranging from regional to national and international levels, e.g., churches, political parties, international courts, including the intervention of UN organizations such as the United Nations Office for Project Services and the Special Rapporteurs on the rights to food and to safe drinking water and sanitation. Mainly at the local level, the alliances of local people with outside actors also play an important role in controlling the ever-present threat of repression of key actors and leaders involved in social mobilization.

Exchange, enhancement, and strengthening of local knowledge played an important role in all four case studies. A scale-related difference between cases was also observed here. At the local level, the exchange of knowledge among local and supporting outside actors was very intense and flowed spontaneously throughout formal and informal interactions between people. Depending on the degree to which the processes of institutional innovation involved broader (intermunicipal or regional) levels of water governance, it has become increasingly important to codify local knowledge, experiences, and visions in formal and more technical or scientific reports, well-organized events, or purposefully managed public campaigns (Ochoa-García 2015). 
The official recognition of the bottom-up institutional innovations was relevant in all four cases. However, in all four cases it is difficult to separate the process of social mobilization of citizens from the formation of political or social movements and the later stage of recognition by an official entity. From the point of view of constitutionality, the institutional innovations express discontent and negative experiences with Mexico's authoritarian political system and its pre-eminence in water governance (Scott and Banister 2008). The achievement of local actors obtaining access to formerly rather closed arenas of political decision-making constitutes a highly interesting element of success. The main factor enabling this outcome is the fact that recognized public bodies, such as communities, municipalities, intermunicipal coordination platforms, or instances of regional governments, nowadays have budgets that they can administer according to their own needs and visions. This allows them to fund additional studies and legal assessments, to cover local actors' expenses for meetings and exchange with outside actors, and to work towards the realization of development and infrastructure projects based on their direct participation in the concrete functioning of the public administration.

\section{Formalization and assignment of concrete responsibilities as a new feature of constitutionality}

The analysis of the case studies revealed an additional element of constitutionality not yet addressed explicitly by Haller et al. (2015). It concerns the process of co-design and formalization of the new institutions, including the transfer or assignation of specific legal, political, and administrative responsibilities, which were previously carried out by governmental officers alone. In this sense, collective action also succeeds in promoting sustainable water governance by transforming the interplay between existing and new institutions; it creates space for local agency and deliberative self-governance based in the principles of water justice as an expression of politics (Isch López 2012). In the case of the CC Cajititlán, the new institution assumed coordinating, counselling, and administrative responsibilities related to the planning, implementation, and monitoring of concrete measures to align environmental and livelihood-related activities with the principles of water justice and the organization's own notions of "development". The creation of a local prosecution office in the same case was also a clear move towards the establishment of a new formal institution that allows for significant improvement of political accountability and subsidiarity of water and environmental governance. In the case of MP El Ahogado, a formal decree defined legal and political responsibilities that are expressed in a work plan with clear indications for interaction with the municipal government and the related public administration (Gobierno de Jalisco 2010). In the case of the IMA Chapala, the institution became a key actor in broadening water governance by expanding its focus on water and lake topics, towards the inclusion of policies addressing land use and forest conservation.

Finally, in the case of the Citizen Observatory, the formalization by the state government defined legal powers for this institution. Some concrete responsibilities are the possibility to issue public recommendations regarding open access to information, integrated research on hydrological resources, development of proposals for land planning, 
accountability and transparency, observation of human rights, promotion of best international practices, tracking research of water-related studies, and deliberation about hydraulic projects based on social participation.

Official recognition and the transfer of jurisdictional powers make the Citizen Observatory an interesting example of a bottom-up institution. Its legitimacy and its ownership by citizens appear to be an appropriate response to social concerns about water, and they have attracted attention throughout the state. Social organizations and municipal governments have been asking the Citizen Observatory for support and advice. However, the state government and formal water agencies still promote mainly technocratic policies that prioritize private investments in hydraulic infrastructure, as well as water and sanitation services (McCulligh and Tetreault 2017; Ochoa-García 2015). Thus, interferences from this "old" way of water policymaking constantly threaten the Citizen Observatory's legitimacy. This might also be the reason why - compared to the other three cases - the Citizen Observatory is viewed as less successful by the people it represents, and receives considerable levels of mistrust. These observations suggest that a high level of social control by local people is required for "their" new institutions. Without increasing social control over such larger institutions, the feedback mechanisms and local social participation might be too weak to effectively resist the temptations offered to local representatives to go along with the interests of more powerful political and business elites, who are not interested in listening to local actors.

\section{Two specific figures of authority in processes of constitutionality for water justice}

Analyzing the four cases using the constitutionality approach reveals another interesting feature of bottom-up institution building processes that has yet to be explored. It concerns the observation that local people recognize the importance of two different roles in catalyzing social mobilization in water conflicts. The distinction between these two roles was only possible due to the intense and long-term participation of the first author of this paper in group meetings, and memories that people recalled in informal conversations. One role or function is defined here as "water caretaker" or "water guard", the other as "water defender". Both types of actors - who have become figures of authority generally appear spontaneously and take part in collective action without being formally appointed by the resistance movements.

Water caretakers have a strong affinity with water as an essential element in nature, life, and social practices. They support universal philosophical reflections on values and principles, profound consciousness of the world's interconnectedness, and devotion to this natural element. In this sense, the practice and knowledge of water caretakers transcends material or merely anthropocentric values, by expressing unconditional commitment to, and solidarity with, those living beings who are vulnerable because they have limited access to water, live in an unhealthy environment, and are losing an important source of livelihood. These leaders play an important role in activating and mobilizing other people during the initial stages of water protests and in consolidating and enhancing social coherence among local citizens engaging in bottom-up institution 
building in the following steps of political mobilization. The water caretaker provides organizational and discursive insights usually gained from social struggles, and which can subsequently be applied to the alliances between local movements and the supporting scientific organizations. In this sense, new institutions are born from creative and lived resistance (Rodríguez-Labajos and Martínez-Alier 2015). During fieldwork in the Santiago River watershed, water caretakers were seen calling to create common fronts for tackling water problems from an integrated and long-term perspective.

Water defenders play an advocacy role, with the aim of promoting improvement of the structural aspects of socio-economic and infrastructure conditions. They say they are doing this especially for poor and marginalized people who require support to increase their well-being, and that through this, they achieve social justice for all people. However, we observed that water defenders' engagement might depend on the circumstances of each specific case, and may be defined in temporal terms by social or political context. Water defenders usually seek to achieve tangible results related to water justice and sustainability. During the fieldwork and public meetings, it was found that water defenders carried out scientific research or organized legal suits against the government and public offices who were promoting top-down initiatives or not fulfilling their responsibility in problems related to dam construction or the deterioration of water bodies. Water defenders frequently work at higher levels of water governance, for example at the interfaces of local and regional action arenas.

While the value of water is defined collectively, these two roles helped to construct the value system to be considered by water institutions at different levels. Water caretakers and water defenders take part in shaping new institutions by incorporating the values of water justice and IWRM. They do so by drawing attention to ways of making power relations more symmetric, in order to create equal access to water or contribute to the enjoyment of the human right to a healthy environment, based on living well in all spheres of life. This echoes Wolf (2012), who states that a comprehensive understanding of water conflicts must encompass the existential, spiritual, knowing, moral-emotional, and physical dimensions by interacting with the different scales of governance beyond hydrological or sociopolitical boundaries.

\section{Linking constitutionality with IWRM and water justice}

The empirical results presented so far provide clear evidence that using the constitutionality lens to look at institution building related to water conflicts offers interesting insights. It provides a framework for understanding water conflicts triggered by top-down water policies as processes that, besides generating resistance against existing institutions, can also trigger institutional innovation.

According to our findings, institutional innovation processes triggered by water conflicts evolved along three interlinked stages (Fig. 2). A first stage focuses on water conflicts as related to resistance to change, and thus to the implementation of top-down technocratic and infrastructure-oriented projects that are often connected to social engineering 
expressed in rigid plans of IWRM. This resistance often coincides with a strong motivation of local actors to develop or strengthen alliances with actors who operate and exert power far beyond the local policy arenas, for example in regional, national, or international courts, as well as with transnational social and political movements or NGOs. This first stage usually involves radical questioning of the values and unjust outcomes associated with top-down water policies, and often leads to the formulation of alternative values based on the principles of water justice.

Fig. 2. Links between constitutionality and IWRM, multilevel governance, and water justice.

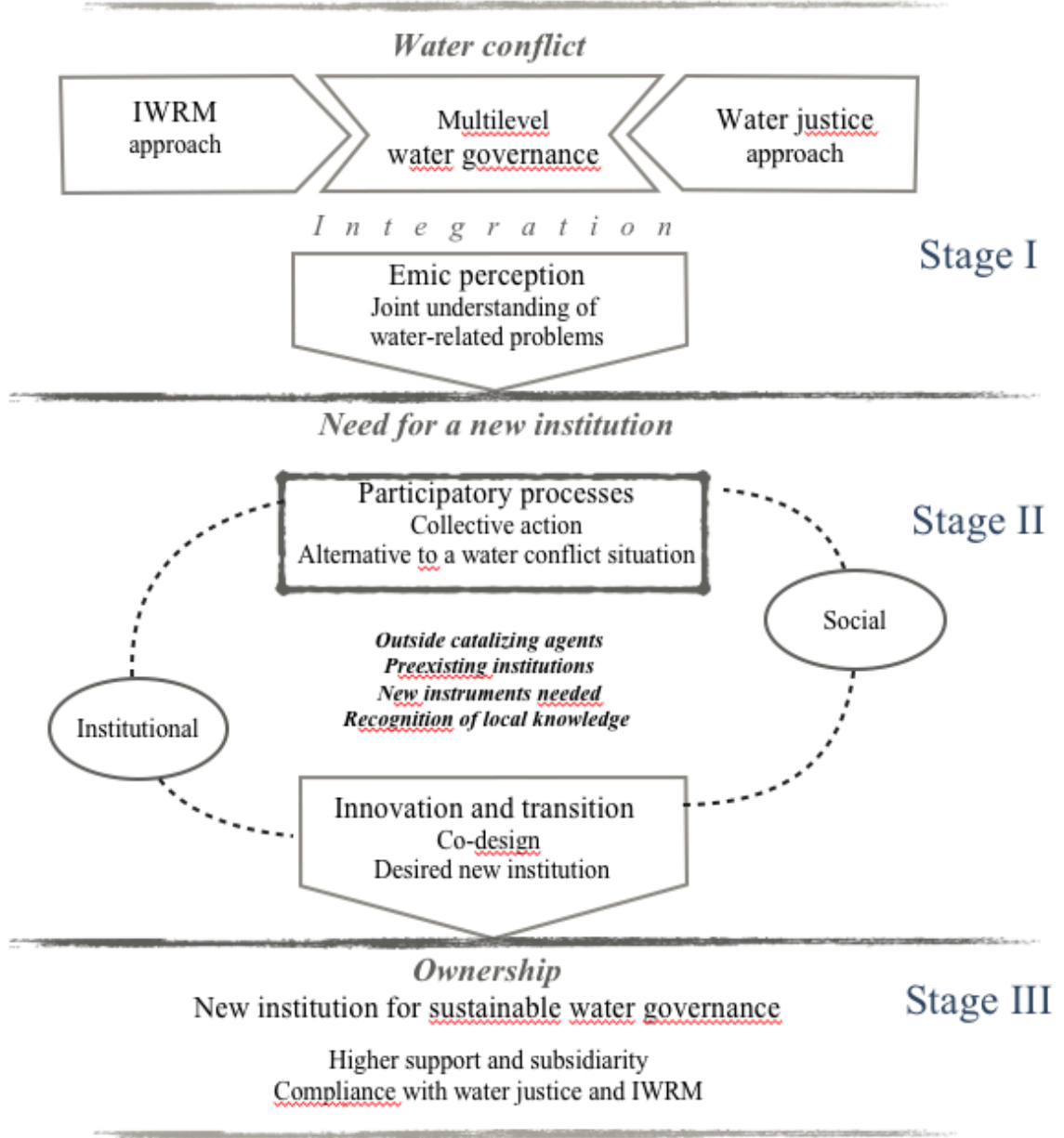

The interplay between IWRM, multilevel governance, and water justice translates into a situation in which the emic perception of the water conflict leads to a framing of problems that counters the problem framings underlying top-down and technocratic approaches to water governance. The new emic framing is based on a shared understanding of the problems by local actors, who express their own views, values, and interests that clearly challenge the powerful actors.

The strengthening of these emic problem framings leads to a second stage in the development of water conflicts concerning the development of new institutions better 
suited to meeting people's views on sustainable water governance. Usually, outside agents such as NGOs, civil-society organizations, and water defenders or water caretakers intervene in the deliberative process represented by this second stage. Moreover, this stage also facilitates the integration of discourses and related local knowledge about resources based on acknowledging monetary and non-monetary values related to ecological and sociocultural functions of water. Eventually, this stage leads to the development of new institutions that are needed to make water governance more sustainable.

In the third stage, the new institutions for more sustainable water governance are linked to existing local, national, and global institutional frameworks, thereby creating a sense of ownership among public as well as private actors, generating higher-level recognition and support, and achieving subsidiarity based on effectively operating new institutions. This process was described in greater detail in the previous chapters.

\section{Discussion and conclusions}

The concept of constitutionality provides a useful approach for analyzing institutional innovations emerging from water conflicts in rural and urban areas of Western Mexico. The growing number of water conflicts showed to be related to a general crisis in water governance (Castro 2007; WWAP 2015). The processes of institutional innovation triggered by the four water conflicts studied here, followed the general principles of constitutionality outlined by Haller et al. (2015). Our study showed that the strengthening of people's own understandings of water justice links mobilization and resistance against top-down water policies with the struggle for bottom-up institutional innovation. This is an interesting new feature in the literature on constitutionality.

Applying the dynamic approach of constitutionality to water conflicts provides meaningful knowledge about civil society's claims and its efforts to achieve IWRM by means of self-crafted institutions. This movement enhances people's capabilities and through this, helps to establish participatory democracy as a means for making established institutions able to consider in their decisions issues related to the human right to safe water and sanitation, minimum ecological flow, as well as principles of water justice by means of equitable access to water, recovery of hydro-ecosystems, and sustainable livelihoods. The transformation of today's water conflicts requires unprecedented levels of political cooperation (Allan 2003; Isch López 2012; Zeitoun and Mirumachi 2008). Looking at constitutionality processes showed ways of responding to this need - which includes transformations of power relations, coalitions, and discourses - as a basis for making water governance more sustainable.

While all four case study areas were in the Santiago River watershed, they presented different contexts and trajectories. At the same time, they all showed similar constitutionality processes. In each case, the water governance policies were radically reshaped in processes driven by local actors' translation of their emic views of water justice into the crafting of new institutions. The institutional innovations described are 
highly specific to their respective contexts and scales. Despite this specificity, constitutionality occurred in quite heterogeneous contexts. In our view, this makes such processes of institutional innovation a promising pathway to sustainable water governance.

The study exposed that the analyzed institutional innovations simultaneously addressed issues related to political rights, justice of water distribution, participation in collective decision-making, improvement of livelihoods, and the restoration of hydro-ecosystems. This enabled local people to continuously monitor the outcomes of the procedural innovations resulting from the constitutionality process. The thus generated powerful array of real-time knowledge can be used to further improve the effectiveness of the ongoing institutional development process.

The cases analyzed showed that processes of constitutionality, in addition to what was documented so far, can also emerge at subnational levels. However, our findings demonstrated that in such cases, weak mechanisms of social control from below can severely hamper the legitimacy and hence the effectiveness of the new institutions that were developed to make water governance more sustainable.

A particularly interesting feature of constitutionality processes at local and regional (subnational) levels is that the locally built new institutions are not only recognized by the state, but may also benefit from the transfer of administrative and legal functions previously fulfilled by the state, such as monitoring compliance with environmental norms or prosecuting and sanctioning actors who fail to comply with existing norms of sustainable water governance. Such a transfer occurred in two of the four cases studied.

Context-sensitivity is a fundamental feature of collective action that can effectively improve sustainable water governance (Schneider and Rist 2013). This was confirmed by the cases examined in this study: Locally emerging "water caretakers" and "water defenders" played pivotal roles in helping to make explicit the rather implicit values of local actors and their notions of water justice. This in turn is a prerequisite for effectively linking resistance against top-down water policies, with bottom-up driven institutional innovation for more sustainable water governance.

Acknowledgements: Heliodoro Ochoa-García acknowledges the support from ProDoc Program headed by the University of St. Gallen and thanks Mario E. López Ramírez for the fruitful exchange of ideas about "water caretakers". Stephan Rist acknowledges support from the Institute of Geography and the Centre for Development and Environment (CDE) of the University of Bern, Switzerland. We also express our gratitude to Marlène Thibault of $\mathrm{CDE}$ for language editing. 
Compliance with Ethical Standards: The authors do not perceive a conflict of interest: Heliodoro Ochoa-García received financial support from ITESO, the Jesuit University of Guadalajara (Scholarship-Number 094743); and CONACYT, Consejo Nacional de Ciencia y Tecnología de México (Scholarship-Number 295011). Stephan Rist is employed by the University of Bern, Switzerland and acts as supervisor of a PhD carried out by the first author.

\section{References}

Allan, Tony. 2003. “IWRM/ WRAM: A New Sanctioned Discourse?” School of Oriental and African Studies Occasional Paper 50: 1-27.

Bakker, Karen. 2013. "Neoliberal Versus Postneoliberal Water: Geographies of Privatization and Resistance". Annals of the Association of American Geographers, 103(2), 253-260.

Boelens, Rutgerd, Edgar Isch López, and Franciso Peña. 2012. "Justicia hídrica: Análisis y acción en contextos cambiantes." In Agua, Injusticia y Conflictos, edited by Edgar Isch López, Rutgerd Boelens, and Franciso Peña, 9-20. Lima: Justicia Hídrica; CBC; Fondo Editorial PUCP; IEP. (Serie Agua y Sociedad, Sección Justicia Hídrica, 2).

Castro, José Esteban. 2007. "Water Governance in the 21st Century." Ambiente \& Sociedade X (2): 97-118.

CEDHJ. 2009. Recomendación 1/2009. Guadalajara, México: Comisión Estatal de Derechos Humanos de Jalisco.

Gobierno de Jalisco. 2010. "Acuerdo del Ciudadano Gobernador Constitucional del Estado de Jalisco. Se emiten los criterios ambientales que deberán observarse para la protección ambiental del polígono con influencia en la zona de la Cuenca El Ahogado." Guadalajara, México: Periódico Oficial del Estado de Jalisco (32 Sección III).

Gobierno de Jalisco. 2014. "Acuerdo del Ciudadano Gobernador Constitucional del Estado de Jalisco, mediante el cual se establecen las bases del Observatorio Ciudadano para la Gestión Integral del Agua para el Estado de Jalisco." Guadalajara, México: Periódico Oficial del Estado de Jalisco (17 Sección III).

Gobierno de México. 2012. El Reto Hídrico En México: Una Carta de Navegación. México D.F.: Gobierno Federal; Semarnat; Conagua.

Haller, Tobias, Greg Acciaioli, and Stephan Rist. 2015. "Constitutionality: Conditions for Crafting Local Ownership of Institution-Building Processes.” Society \& Natural Resources 29 (1): 68-87.

IMTA, and CEAJ. 2011. Actualización Del Estudio de Calidad Del Agua Del Río Santiago (Desde Su Nacimiento En El Lago de Chapala Hasta La Presa Santa Rosa) Informe Final. Edited by Jorge Izurieta Dávila and Pilar Saldaña Fabela. IMTA; CEAJ.

Isch López, Edgar. 2012. "Justicia Hídrica: Una Sistematización Conceptual Introductoria." In Agua, Injusticia Y Conflictos, edited by Edgar Isch López, 
Rutgerd Boelens, and Francisco Peña, 21-44. Lima: Justicia Hídrica; CBC; Fondo Editorial PUCP; IEP.

López-Ramírez, Mario Edgar, and Heliodoro Ochoa-García. 2012. "Geopolítica Del Agua En La Zona Metropolitana de Guadalajara: Historia Y Situación Del Espacio Vital." In Gobernanza y Gestión Del Agua En El Occidente de México: La Metrópoli de Guadalajara, edited by Heliodoro Ochoa-García and Hans Joachim Bürkner, 33-72. Guadalajara, México: ITESO.

Martínez-Alier, Joan, Leah Temper, Daniela del Bene, and Arnim Scheidel. 2016. "Is There a Global Environmental Justice Movement?" Journal of Peasant Studies 43(3): 731-755.

McCulligh, Cindy and Darcy Tetreault. 2017. "Water management in Mexico. From Concrete-Heavy Persistance to Community-Based Resistance". Water Alternatives, 10(2), 341-369.

McCulligh, Cindy, Cecilia Lezama, and Lizette Santana, eds. 2016. Las políticas del deterioro: la dinámica urbano- industrial en torno al río Santiago, Jalisco, México. WATERLAT-GOBACIT Network Working Papers Thematic Area Series -TA3- Urban Water Cycle and Essential Public Services. Vol. 3. Newcastle Upon Tyne, UK and Guadalajara, Jalisco, México: Waterlat-Gobacit Network.

Ochoa-García, Heliodoro, ed. 2015. Imposition, resistance, and alternatives in the face of an inter-regional water crisis in Mexico: El Zapotillo project (in Spanish). WATERLAT-GOBACIT Network Working Papers Thematic Area Series SATCTH - TA6 - Basins and Hydrosocial Territories. Vol. 2. Newcastle Upon Tyne, UK and Guadalajara, México: Waterlat-Gobacit Network.

Ochoa-García, Heliodoro, Pedro Arrojo-Agudo, Jonatan Godínez-Madrigal, Pablo López-Villegas, Alejandro López-Aguayo, and Marcela Livier QuirozHernández. 2014. "Agua Para El Desarrollo Regional En Los Altos de Jalisco, Gestión Del Agua E Impacto Social Del Proyecto El Zapotillo.” Guadalajara, México (research report).

Ochoa-García, Heliodoro, and Hans Joachim Bürkner, eds. 2012. Gobernanza Y Gestión Del Agua En El Occidente de México: La Metrópoli de Guadalajara. Guadalajara, México: ITESO.

Ochoa-García, Heliodoro, and Stephan Rist. 2015. "La Emancipacion Como Posibilidad Para Transitar Hacia Una Gobernanza Sustentable Del Agua." WATERLATGOBACIT Network Working Papers Thematic Area Series SATCTH - TA6 Basins and Hydrosocial Territories 2 (1): 12-45.

Reis, Nadine. 2014. "Coyotes, Concessions and Construction Companies: Illegal Water Markets and Legally Constructed Water Scarcity in Central Mexico." Water Alternatives 7 (3): 542-60.

Rodríguez-Labajos, Beatriz, and Joan Martínez-Alier. 2015. "Political Ecology of Water Conflicts." WIREs Water 2 (5): 537-58.

Schlosberg, David. 2007. Defining Environmental Justice: Theories, Movements, and Nature. Oxford University Press. 
Schneider, Flurina, and Stephan Rist. 2013. "Envisioning Sustainable Water Futures in a Transdisciplinary Learning Process: Combining Normative, Explorative, and Participatory Scenario Approaches." Sustainability Science 9 (4): 463-81.

Scott, Chistopher. A., and Jeff M. Banister. 2008. "The dilemma of water management "regionalization" in Mexico under centralized resource allocation". International Journal of Water Resources Development, 24(1), 61-74.

Semadet. 2013. Plan estratégico del polígono de fragilidad ambiental de la cuenca El Ahogado. Guadalajara, México: Semadet, Gobierno de Jalisco.

Semarnat. 2004. "DECRETO por el que se reforman, adicionan y derogan diversas disposiciones de la Ley de Aguas Nacionales," México D.F.: Diario Oficial de la Federación (April 29), Secretaria de Gobernación, Estados Unidos Mexicanos.

Tetreault, Darcy, Heliodoro Ochoa-García, and Eduardo Hernández-González, eds. 2012. Conflictos Socioambientales Y Alternativas de La Sociedad Civil. Guadalajara, México: ITESO.

Toledo, Víctor M., David Garrido, and Narciso Barrera-Bassols. 2015. "The Struggle for Life: Socio-Environmental Conflicts in Mexico." Latin American Perspectives 42 (5): 133-47.

Velázquez-López, Laura, Heliodoro Ochoa-García, and Jaime Morales-Hernández. 2012. "Agua Y Conflictos Ambientales En La Ribera de Cajititlán, Jalisco." In Conflictos Socioambientales Y Alternativas de La Sociedad Civil, edited by Darcy Tetreault, Heliodoro Ochoa-García, and Eduardo Hernández-González, 181-214. Guadalajara, México: ITESO.

Wester, Philippus, Eric Mollard, Paula Silva-Ochoa, and Sergio Vargas-Velázquez. 2009. "From Half-Full to Half-Empty: The Hydraulic Mission and Water Overexploitation in the Lerma-Chapala Basin, Mexico." In River Basin Trajectories: Societies, Environments and Development, edited by Francois Molle and Philippus Wester, 75-98. Oxfordshire and Cambridge: CABI, IWMI.

Wolf, Aaron T. 2012. "Spiritual Understandings of Conflict and Transformation and Their Contribution to Water Dialogue." Water Policy 14 (SUPPL. 1): 73-88.

World Economic Forum. 2016. "The Global Risks Report 2016 11th Edition," 103.

WWAP. 2015. "The United Nations World Water Development Report 2015: Water for a Sustainable World." Paris: UNESCO.

Zeitoun, Mark, and Naho Mirumachi. 2008. "Transboundary Water Interaction I: Reconsidering Conflict and Cooperation." International Environmental Agreements: Politics, Law and Economics 8 (4): 297-316.

Zwarteveen, Margreet Z., and Rutgerd Boelens. 2014. "Defining, Researching and Struggling for Water Justice: Some Conceptual Building Blocks for Research and Action." Water International 39 (2). Routledge: 143-58. 